\title{
NILAI-NILAI EDUKASI DALAM SENI REYOG PONOROGO
}

\author{
Rido Kurnianto dan Niken Lestarini \\ Fakultas Agama Islam Universitas Muhammadiyah Ponorogo \\ Email: kurnianto.mama@gmail.com
}

\begin{abstract}
This study examined the character education of Konco Reyog at schools viewed from the meaning of Reyog Ponorogo's art symbol. Then, it has tried to reveal its relevance with Islamic education. The data were obtained from the key persons, i.e. warok figure, Reyog Foundation, Reyog teachers, and the supporting artists, which then were described qualitatively to arrange character education module of Konco Reyog based on Islamic education. The finding shows that Reyog's symbol is loaded with value and meaning, including the educational values. These values have very strong relevance with several values contained in Islamic education. Further, these values are built systematically through school. Its position is quite strong as it is included in the curriculum of intra-curricular as a local content based on the local wisdom. These Reyog Ponorogo art values are possible to be alternative models for character education in order to build noble values and meanings based on Islamic education.
\end{abstract}

Penelitian ini mengkaji pendidikan karakter Konco Reyog di sekolah-sekolah yang digali dari makna simbol seni Reyog Ponorogo. Selanjutnya muatan tersebut dikaji basis relevansinya dengan pendidikan Islam, yang selama ini belum tersentuh. Data yang diperoleh dari orang kunci (key person), yaitu tokoh warok, yayasan Reyog, para pengampu pembelajaran Reyog, dan para seniman pendamping, dideskripsikan secara analitis kualitatif untuk menyusun modul pendidikan karakter Konco Reyog berbasis pendidikan Islam. Temuan pokok penelitian ini adalah bahwa dalam seni Reyog Ponorogo memiliki sejumlah simbol yang sarat dengan nilai dan makna, diantaranya adalah nilai pendidikan. Nilai-nilai tersebut memiliki relevansi yang sangat kuat dengan sejumlah nilai yang terkandung di dalam pendidikan Islam. Pada perkembangannya, nilainilai pendidikan dalam seni Reyog Ponorogo ditanamkan secara sistematis 
melalui lembaga pendidikan sekolah. Posisinya cukup kuat karena masuk dalam kurikulum intrakurikuler sebagai muatan lokal berbasis kearifan lokal. Nilai-nilai pendidikan berbasis seni Reyog Ponorogo ini sangat dimungkinkan menjadi alternatif model pendidikan karakter dalam rangka menanamkan nilai dan makna hidup luhur berbasis pendidikan Islam.

Keywords: Konco Reyog, Character Education, Islamic Education, Model

\section{Pendahuluan}

Maraknya perilaku tidak terpuji dan belum optimalnya lembaga pendidikan dalam menanamkan karakter melahirkan sejumlah gagasan untuk membenahi sistem pendidikan. Di antaranya dengan memasukkan budaya lokal sebagai unsur penting muatan kurikulumnya. Seiring dengan itu, pendidikan melalui basis budaya lokal, komunitas/paguyuban masyarakat juga mulai digalakkan, termasuk komunitas pelaku seni Reyog Ponorogo yang akrab dengan sebutan Konco Reyog.

Sejak dikenal masyarakat Ponorogo, seni Reyog Ponorogo sarat dengan paduan harmonis antara warna Animisme, Dinamisme, Hindu, Budha, dan Islam. Paduan harmonis itu terlihat jelas pada perangkat Dadak-Merak (Barongan): dua binatang "mistis" (Harimau dan Burung Merak), dan manik tasbih yang menggantung pada paruh Burung Merak. Sejak lima belas tahun terakhir, tidak sedikit lembaga pendidikan Islam, termasuk pondok pesantren modern di Ponorogo, yang telah memberanikan diri untuk menjadikan seni Reyog Ponorogo sebagai satu diantara pilihan kegiatan ekstrakurikuler. Dikatakan memberanikan diri karena sebelumnya kalangan muslim santri "enggan" untuk berkesenian Reyog karena dianggap sarat dengan perilaku yang bertentangan dengan ajaran Islam, seperti mabuk-mabukan, marok (sikap sombong), praktik pagan lewat sesaji, dan sebagainya. Pondok Modern Ar-Risalah Slahung Ponorogo bahkan telah berani menyelenggarakan festival seni Reyog Ponorogo di kampus pesantrennya pada tahun 2002 yang lalu.

Seiring waktu, di tengah pergumulan dengan banyak konteks, Seni Reyog Ponorogo melahirkan jenis dan variasi yang beragam, dimana dalam keragaman itu di samping memperkaya khazanah Seni Reyog Ponorogo juga memunculkan friksi dalam konotasi negatif, yakni klaim kebenaran masingmasing ragam atau versi (Kurnianto, 2013: 2-3). Fakta terjadinya klaim kebenaran di lingkungan Konco Reyog ini kemudian diperparah dengan munculnya definisi-definisi tentang Reyog Ponorogo yang asli dan yang tidak asli (bukan seni Reyog Ponorogo yang berbasis konteks Ponorogo). Di kalangan tokoh 
Warok, perebutan klaim ini telah melahirkan dua kubu dengan paradigma tentang seni Reyog yang saling berseberangan: Kubu Timur dan Kubu Barat (Kurnianto, 2013: 49)

Kubu Timur ini memiliki sudut pandang bahwa Reyog Ponorogo yang asli adalah Reyog yang dipentaskan untuk kepentingan pentas rakyat, yakni pentas apa adanya dan masih memegang prinsip dan warisan nenek moyang (menjaga ritual, menjaga sesaji). Kubu Timur ini di kemudian melahirkan nuansa Reyog dengan pentas Obyog (Kurnianto, 2013: 49-50). Sementara Kubu Barat memiliki sudut pandang bahwa Reyog Ponorogo merupakan kesenian yang harus disikapi secara dinamis, menyangkut konsep pentas maupun pengembangan tarinya. Bagi Kubu Barat, pelestarian dan pengembangan Reyog Ponorogo tidak harus berlatar konteks jaman dulu, sekalipun tidak bisa terlepas dari konteks jaman dulu (historisitas kesejarahan). Warisan budaya nenek moyang tetap dipegang dan dihargai, tetapi dimaknai secara kontekstual. Kubu Barat ini lalu melahirkan seni Reyog Garapan (Reyog Panggung), dan konsep inilah yang melatarbelakangi penyelenggaraan Festival Reyog Nasional (FRN) yang dilakukan secara rutin setiap tahun.Situasi ini berkembang menjadi sikap-sikap eksklusif masing-masing Konco Reyog hingga melahirkan sikap "saling menyalahkan". Versi atau ragam tersebut meliputi: Reyog Obyog, Reyog Garapan/Reyog Panggung, dan Reyog Santri.

Dalam pentas terdapat perbedaan cukup mencolok antar versi Reyog Ponorogo. Reyog Obyog lebih mengedepankan hiburan rakyat. Reyog Panggung lebih menonjolkan kreasi tari/seni. Sementara Reyog Santri lebih mengedepankan simbol-simbol dan makna islami. Ketiga versi seni Reyog Ponorogo, sekalipun memiliki ciri khas masing-masing, tetapi secara umum memiliki kesamaan pada aspek formulasi nilai budaya yang ada secara potensial maupun aktual yang dikandung dalam instrumen maupun ragam tarinya.

Fakta yang cukup unik sebenarnya adalah dimasukkannya seni Reyog Ponorogo ke dalam kurikulum sekolah, baik intra maupun ekstrakurikuler. Dimasukkannya seni Reyog Ponorogo ke dalam pembelajaran di sekolah, di samping karena tuntutan seni, juga adanya fakta tentang maraknya pentas Reyog Ponorogo yang sarat dengan perilaku "kontra produktif" dengan nilainilai luhur yang terbabar dalam simbol-simbol budayanya. (Kurnianto, 2013: 52) Perilaku kontra produktif tersebut antara lain: mabuk-mabukan (minum khamr), ritual sesaji menjelang pentas, saweran (memberi hadiah berupa uang kepada penari jathil yang dilakukan penonton pria dengan menyentuk bagian "sensitif" dari tubuh penari), adopsi kekuatan mistik, dan sebagainya yang 
kesemuanya dianggap bertentangan dengan norma sosial maupun norma agama (Islam). Tradisi mabuk-mabukan, bahkan sudah menjadi rahasia umum di kalangan Konco Reyog Ponorogo. Beberapa oknum Konco Reyog terkadang masih memiliki rasa malu dan karena itu mereka memilih meminum khamr itu jauh sebelum pentas dan dilakukan di tempat yang tersembunyi. Namun tidak sedikit pula yang secara terang-terangan meminum khamr di area pentas. Bahkan ada "norma ilegal" dengan dibakukannya tradisi minum khamr untuk memperkuat pentas (adanya keyakinan bahwa reaksi minuman keras tersebut akan berpengaruh pada keberanian dan kekuatan pada saat mementaskan seni Reyog Ponorogo).

Sementara, ada fakta unik lainnya seiring dengan maraknya apresiasi masyarakat terhadap seni Reyog Ponorogo, yaitu kenyataan bahwa perilaku Konco Reyog yang "menyimpang" sebagaimana dipaparkan diatas, di negerinya sendiri -Ponorogo, kesenian ini ternyata kurang mendapatkan apresiasi yang sebanding dengan kebesarannya di tingkat nasional (Kurnianto, 2013: 52-53). Jadi, yang terjadi adalah semacam "apresiasi semu" yang disebabkan oleh adanya "gap" antara pesan-pesan mulia yang diusung oleh seni adiluhung ini dengan pementasan yang justru bertolak belakang dengan simbol-simbol seni yang dipentaskan.

Pesan-pesan luhur seni Reyog Ponorogo melalui simbol-simbolnya akan teraktualisasikan secara baik jika dipadukan dengan nilai-nilai pendidikan (Islam). Mengusung seni Reyog ke dalam pembelajaran sekolah paling tidak dikarenakan oleh dua alasan: (1) maraknya kerusakan moral yang melanda masyarakat secara luas, termasuk di kalangan anak-anak usia sekolah, sehingga seni Reyog ini menjadi pilihan sebagai media menangkal dekadensi moral melalui aktualisasi potensi pesan-pesan luhur pada seni budayanya; (2) saratnya pesan moral dan nilai pendidikan yang terdapat di dalam instrumen dan tari Reyog Ponorogo, sehingga diperlukan pengelolaan aspek ini secara baik. Sehingga, penanaman karakter mulia pada Konco Reyog dan masyarakat luas juga akan berkembang menjadi pilihan pelestarian dan pengembangan seni Reyog Ponorogo.

Watak (karakter) merupakan seperangkat sifat yang selalu dikagumi sebagai tanda-tanda kebaikan, kebijakan, dan kematangan moral seseorang (Zuhdi, 2008: 39). Berdasarkan watak, seseorang dididik, dibina, dan dikembangkan ke arah penguatan agar berkembang dalam citra yang baik. Dalam praktik, pembangunan atau pendidikan karakter selalu dikaitkan dengan nilai (Frondizi, 2011: 1-3) atau tradisi yang berkembang di tengah masyarakat, yang menurut 
mereka perlu diwariskan dari generasi ke generasi berikutnya.

Sejumlah nilai pendidikan yang melekat dalam seni Reyog Ponorogo bisa ditransformasikan kepada Konco Reyog mengingat seni ini cukup memperoleh apresiasi dari masyarakat luas, termasuk masyarakat pendidikan. Tujuan pendidikan karakter adalah mengajarkan nilai-nilai tradisional tertentu, yang diterima secara luas sebagai landasan perilaku yang baik dan bertanggungjawab. Hal ini untuk menumbuhkan rasa hormat, tanggungjawab, rasa kasih sayang, disiplin, loyalitas, keberanian, toleransi, keterbukaan, etos kerja, dan kecintaan kepada Tuhan dalam diri seseorang (Zuhdi, 2008: 77). Keseluruhan karya sastra, seni, dan budaya juga merupakan salah satu sumber pendidikan karakter (Ratna, 2014: 195). Di saat banyak orang sudah tidak lagi percaya kepada orang tua, pemimpin, dan pemerintah, bahkan dengan agama sekalipun, maka tidak menutup kemungkinan karya sastra, seni, dan budaya menjadi sumber terpenting pendidikan karakter. Sesuatu yang disampaikan secara estetis, etis, dan logis, akan membuat manusia lebih percaya terhadap seni budaya dibandingkan dengan narasi-narasi ilmu pengetahuan, termasuk agama (Ratna, 2014: 195-196).

\section{Metode Penelitian}

Penelitian ini merupakan jenis penelitian kualitatif dengan pendekatan fenomenologi budaya. Data penelitian digali dari orang-orang kunci (key person), yakni para tokoh Reyog Ponorogo (Warok), Yayasan Reyog Ponorogo, Dinas Pariwisata, Pemuda, dan Olahraga Kabupaten Ponorogo, para pengampu mulok Reyog Ponorogo di sekolah-sekolah yang diteliti, serta para seniman pendamping. Metode pengumpulan data meliputi wawancara mendalam, observasi partisipan aktif, dan diskusi terfokus. Sedangkan analisis data menggunakan deskriptif kualitatif.

\section{Nilai-Nilai Pendidikan dalam Seni Reyog Ponorogo}

Nilai pendidikan seni Reyog Ponorogo tersebar di dalam instrumen seni dan ragam tarinya. Secara rinci nilai-nilai pendidikan pada seni Reyog Ponorogo adalah sebagai berikut:

Pendidikan keimanan. Sebelum seni Reyog dipentaskan, lazimnya dilakukan ritual/upacara untuk memohon kekuatan. Di kalangan Konco Reyog yang berlatar Animisme-Dinamisme, Hindu, dan Budha, ritual dilakukan untuk menghadirkan "roh" harimau dan merak, dengan tujuan agar mampu melakukan pentas dengan aman dan tertib (atas kharisma harimau), dan 
mementaskan seni Reyog dengan indah memesona (atas kharisma merak) "Latar keyakinan, latar keagamaan yang beragam pada diri "jawara" Ponorogo yang selalu peduli kepada pelestarian dan pengembangan Reyog Ponorogo, janganlah diusik. Biarkan masing-masing mengalir mengikuti arah angin peradaban unggul yang ingin diukirnya di bumi Reyog ini. Andai tidak mampu terkumpul di dalam ukhuwah keagamaan atau keyakinan, biarlah para jagoan (warok) itu bersatu di dalam $u$ khuwat wathaniyyat (kesatuan yang terpayungi oleh satu kepentingan memajukan kota Reyog ini) dengan salah satunya melalui seni Reyog Ponorogo” (Tobroni Toredjo, wawancara, 7 Juli 2015).

Pendidikan budi pekerti. Instrumen pokok Reyog Ponorogo (kepala harimau dan merak) menjadi karakter sentral yang dituju oleh keseluruhan pentas seni Reyog Ponorogo. Kuat dan indah merupakan dua pilar kepribadian utama, dan pesan ini yang diharapkan terbabar di dalam keseluruhan pentas seni Reyog Ponorogo dan sekaligus mendasari seluruh filosofi berseni Reyog Ponorogo (Budi Satriyo, wawancara, 15 Juli 2015).

Pendidikan jasmani dan rohani. Manik-manik yang tergantung di paruh burung merak memang tidak baku bentuk dan materinya, tergantung pada selera Konco Reyog yang memilikinya. Tetapi apapun bentuknya, sebenarnya manik-manik itu adalah dimaksudkan sebagai alat penghitung dzikr saat seorang Muslim melakukan $d z i k r$ kepada Allah SWT. Dengan demikian manik tasbih ini menjadi media empiris yang bisa dipakai sebagai pintu masuk islamisasi Reyog Ponorogo.

Manik-manik itu dimaksudkan juga sebagai mutiara yang keluar dari mulut burung merak. Artinya, adalah sebuah penggambaran pribadi yang telah memperoleh kekuatan diri secara lahir dan batin, fisiknya kuat seperti kekuatan seekor harimau, psikisnya juga kuat sebagaimana kharisma raja hutan (kanoragan tinggi), maka yang keluar dari diri pribadi seperti ini tiada lain adalah permata dan mutiara hidup yang akan selalu memberikan kemanfaatan kepada semesta ini (Budi Satriyo, wawancara, 15 Juli 2015).

Pendidikan kepemimpinan. Nilai pendidikan aspek kepemimpinan ini terdapat di dalam Tari Klanasewandana. Tari ini dikemas untuk mementaskan kharisma kepemimpinan Prabu Klanasewandana yang gagah berani, sakti mandraguna, hingga melalui senjata pamungkasnya yang bernama Pecut Samandiman mampu melumpuhkan Singa Barong, perwujudan raja hutan yang kuat dan buas. Di dalam praktik kepemimpinan, tari ini bisa dikemas dengan alur yang menandai sebuah kepemimpinan yang amanah. Klanasewandana yang diyakini sebagai seorang raja sakti mandraguna, bisa dimunculkan sebagai 
simbol seorang pemimpin yang seharusnya memimpin rakyat: memiliki ilmu dan pengalaman yang luas, memiliki fisik yang sehat dan kuat, profesional, dan amanah, serta taat kepada Sang Pencipta (Marji, wawancara, 3 Agustus 2015).

Pendidikan kewiraan. Nilai pendidikan kewiraan ini terbabar di dalam Tari Kuda (Jathil). Tari Jathil yang pada awalnya diperankan oleh penari laki-laki ini dimaksudkan sebagai simbol sikap patriotisme (kepahlawanan) yang dimiliki oleh generasi pewaris peradaban Ponorogo, sebuah sikap yang selalu siap siaga/waspada untuk menyongsong hari esok dengan sejumlah ketrampilan dan kecakapan hidup yang diperlukan dalam membangun peradaban unggul. Tari ini tidak sekedar bermakna ketangkasan generasi bangsa di dalam berperang menghadapi musuh dari luar, tetapi yang lebih penting adalah berperang melawan hawa nafsu yang berada di dalam dirinya sendiri. Karena itu, tampilan tarinya harus mencerminkan ketegasan, kewaspadaan, dan kecermatan. Pandangan mata yang tajam menatap lurus ke depan adalah sebuah sikap yang selalu berorientasi ke masa depan. Sementara gerakan kepala menengok ke kiri dan kanan adalah sebuah gambaran sikap bagaimana mereka secara cerdas melihat konteks jaman yang mengitari. Atas simbol sikap seperti itulah, Tari Jathil menjadi tidak tepat ketika dibawakan dengan lemah gemulai, apalagi mengandung erotisme, sekalipun penarinya adalah wanita (Marji, Tanggal 3 Agustus 2015).

Pendidikan kesabaran dan optimisme. Nilai pendidikan yang lahir dari Tari Pujangganong (Pujangga Anom) yang terkesan lucu, banyak ulah, dan selalu membuat sensasi adalah simbol bahwa hidup di dunia ini tidak selalu mulus dan lurus. Tari Pujangganong ini, tidaklah sekedar bernilai hiburan yang memukau, tetapi mengandung makna yang begitu dalam, bahwa generasi pewaris bumi Reyog ini adalah orang-orang yang selalu optimis menghadapi hidup dengan terus membentengi diri dengan sejumlah ilmu, ketrampilan, dan kebesaran jiwa untuk meretas masa depan gemilang (Marji, wawancara, 3 Agustus 2015).

\section{Pilar Pendidikan Islam Berbasis Seni Reyog Ponorogo}

Berdasarkan uraian tentang nilai-nilai pendidikan pada seni Reyog Ponorogo, maka secara spesifik di dalamnya terkandung pilar pendidikan Islam, yakni: akidah, ibadah, dan akhlak yang terbabar di dalam makna simbol, baik yang terkandung di dalam instrumen alatnya maupun ragam tarinya.

Pilar pendidikan akidah (keimanan) terbabar dalam dua aspek, yakni 
pembuka pentas dan pada simbol senjata Pecut Samandiman (senjata milik Raja Kelanasewandana berbentuk sejenis cemeti). Pembuka pentas seni Reyog menjadi pendidikan keimanan karena ketika konco Reyog mengawali pentas mereka mengawalinya dengan memanjatkan doa kepada Allah SWT, melalui berbagai kreasi (sikap, syair lagu (tembang), tari, dan sebagainya). Di semua sekolah yang telah penulis teliti (12 sekolah), semua pentas dimana dan dalam bentuk apapun selalu diawali dengan berdoa bersama. Sementara pilar pendidikan keimanan yang terbabar dalam makna simbol Pecut Samandiman, terbaca dalam komposisi pecut, yakni terdapat lima ikat dan satu pilar. Lima ikat dimaksudkan sebagai rukun Islam yang lima (syahadat, shalat, puasa, zakat, dan haji). Sedangkan satu pilar berupa cemeti adalah simbol tauhid (keesaan Tuhan). Karena itu, di dalam pentas, ketika senjata ini dipergunakan untuk melawan Singabarong (Dhadhak Merak) yang konon kuat tidak terkalahkan, maka ia langsung ambruk tidak berdaya, bahkan semesta di sekelilingnya ikut terkena dampak yang sangat merusakkan. Hal ini dimaksudkan sebagai gambaran bahwa ketika seseorang telah beriman dengan kuat kepada Tuhan disertai dengan pengamalan rukun Islam, maka tidak akan ada kekuatan apapun di semesta ini yang bisa melemahkannya, karena dirinya telah terpaut kuat dengan kekuatan Tuhan Yang Maha Kuasa.

Secara rinci pilar-pilar pendidikan, baik yang terkandung di dalam instrument maupun ragam tari seni Reyog Ponorogo sebagaimana dipaparkan di bawah ini:

Instrumen Reyog

Pertama, Reyog/Dhadak Merak. Berasal dari bahasa Arab "riyaqun" berarti: "keindahan, kebaikan yang mengagumkan" (Munawwir, 1984:560). Manusia harus selalu mendekatkan diri kepada Tuhan dengan ketaatan kepada Nya, sehingga mampu melalui hidup dan mengakhirinya dengan tetap berada di jalan Nya. Alqur'an menjelaskan pilar ini di dalam QS Ali Imran: 102 : "Bertaqwalah kepada Allah dengan sebenar-benar taqwa dan janganlah sekali-kali kamu mati, kecuali dalam keadaan memeluk Islam”.

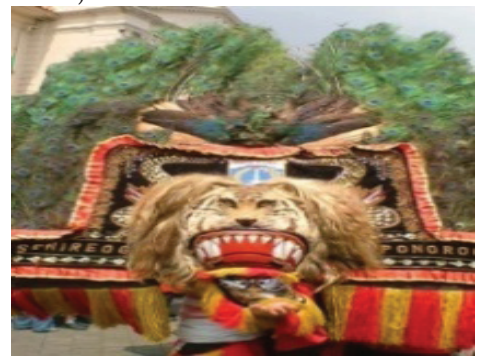

Gambar 1: Reyog/Dhadhak Merak

el Harakah Vol.17 No.2 Tahun 2015 
Kedua, Kendang. Berasal dari bahasa Arab "qada'a” yang berarti : mengendalikan (Munawwir, 1984: 1179). Manusia harus pandai mengendalikan hawa nafsunya agar tidak terjerumus ke dalam perbuatan yang tercela, melanggar aturan/norma agama, merugikan orang lain, dan seterusnya.

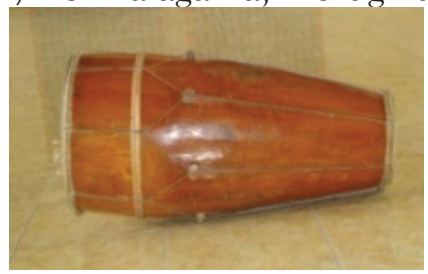

Gambar 2: Kendang

Ketiga, Ketipung. Berasal dari bahasa Arab "katifun" yang berarti : balasan (Munawwir, 1984: 1281). Manusia harus hati-hati dengan setiap perbuatan yang dilakukannya, karena semuanya harus dipertanggungjawabkan di hadapan Tuhan dan akan memperoleh balasan yang setimpal di pengadilan akhirat nanti. Oleh karena itu harus diupayakan agar semua perbuatannya baik dan sesuai dengan tuntunan agama.

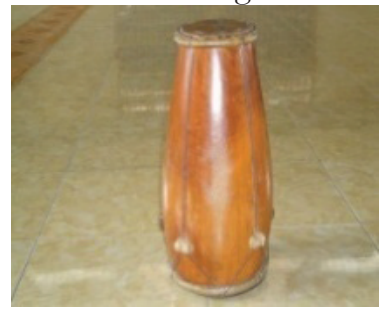

Gambar 3: Ketipung

Keempat, Kenong. Berasal dari bahasa Arab "qana'a" yang berarti : puas dengan bagiannya (Munawwir, 1984: 1250). Manusia wajib berusaha untuk memperoleh kehidupan yang terbaik. Bersamaan dengan itu, manusia juga harus menyadari dengan sepenuhnya bahwa setiap upaya akan menemui kepastian hasil sesuai dengan kehendak Tuhan. Oleh karena itu, manusia harus menerima dengan ikhlas apapun hasil yang ditentukan oleh Tuhan dengan banyak bersyukur dan bersabar. Dalam riwayat Abdullah bin 'Amr Rasulullah SAW bersabda: "Sungguh beruntung orang yang diberikan petunjuk masuk Islam, diberi kecukupan rizki, dan merasa cukup terhadap apa yang diberikan kepadanya" (Sunan Ibnu Majah Hadis nomor 4138, tt. : 1386).

Kelima, Kethuk. Berasal dari bahasa Arab "khatha" yang berarti: salah (Munawwir, 1984: 376). Manusia harus menyadari sepenuhnya, bahwa sebaik apapun manusia, mestilah ia akan berbuat kesalahan/dosa. Karena itu sebaik-baik manusia, bukanlah orang yang tidak bersalah/berdosa, karena hal 
itu tidak mungkin, tetapi manusia yang baik adalah orang yang melakukan kesalahan/dosa kemudian segera bertaubat kepada Allah.

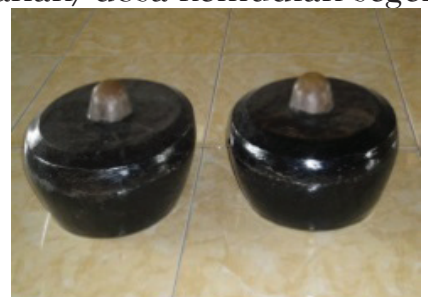

Gambar 4: Kenong dan Kethuk

Keenam, Angklung. Berasal dari bahasa Arab "intiqal", yang berarti: bergerak, berhijrah (Munawwir, 1984: 1557). Manusia harus senantiasa melakukan hijrah (bergerak/berpindah) dari keburukan/kejahatan (melanggar aturan, norma, ketaatan) menuju kepada kebaikan (terpuji).

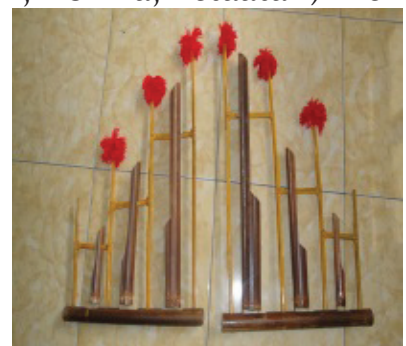

Ketujuh, Terompet. Berasal dari bahasa Arab "shuwarun" artinya : penggambaran (Munawwir, 1984: 859). Manusia harus selalu menyadari bahwa hidupnya menuju kematian, dan perjalanan hidupnya seiring usianya yang terus berkurang akan semakin mendekati kematian. Karena itu manusia harus menyiapkan bekal yang cukup agar kelak ketika ia harus mempertanggungjawabkan perbuatannya di hadapan Tuhan, ia menerima kebaikan dan pahala dari Tuhan dengan kenikmatan surgaNya.

Kedelapan, Kempul. Berasal dari Bahasa Arab "kafulun" yang berarti: balasan (Munawwir, 1984: 1311). Setiap perbuatan buruk akan dibalas dengan keburukan berupa siksa dan penderitaan. Demikian halnya setiap perbuatan baik akan memperoleh balasan kebaikan berupa kebahagiaan.

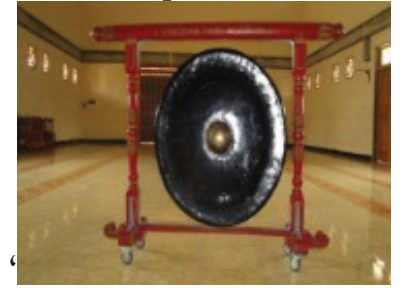

Gambar 6: Kempul

el Harakah Vol.17 No.2 Tahun 2015 
Kesembilan, Kolor/Usus-usus. Berasal dari bahasa Arab "ususun” yang berarti: dasar, landasan (Munawwir, 1984: 26). Agar hidup manusia sempurna, maka ia harus memegang erat tali Allah (hablun min Allah) dengan ketataan/ pengabdian yang sempurna. Bersamaan dengan itu, manusia juga harus memegang tali untuk membangun hubungan antar sesama (hablun min al-nas), hubungan dengan sesama manusia. Kedua tali (vertikal dan horizontal) ini menjadi syarat manusia akan menjadi insan kamil (manusia yang sempurna/ mulia).

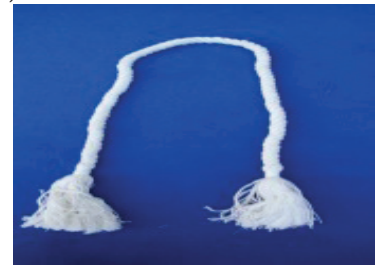

Gambar 7: Kolor/usus-usus

Kesepuluh, Baju Penadon. Berasal dari bahasa Arab "fanadun" yang berarti : kelemahan (Munawwir, 1984: 1154). Manusia harus sadar, bahwa setiap manusia memiliki kelemahan. Oleh karena itu, ia tidak layak berbuat sombong, apalagi jika kesombongan itu ditujukan kepada Tuhan.

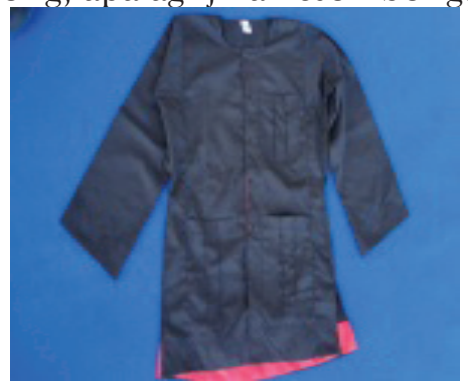

Gambar 8: Baju Penadon

Kesebelas, Udheng. Berasal dari bahasa Arab " $u d$ ' $u$ " yang berarti: mengajak, menganjurkan (Munawwir, 1984: 439). Manusia harus saling mengajak, saling menganjurkan melalui doa dan dakwah. QS Al-'Ashr: 1-3: "Demi masa. Sesungguhnya manusia akan mengalami kerugian, kecuali orang-orang yang beriman, beramal salih, saling menasihati dalam hal kebaikan dan saling menasihati dalam hal kesabaran." 


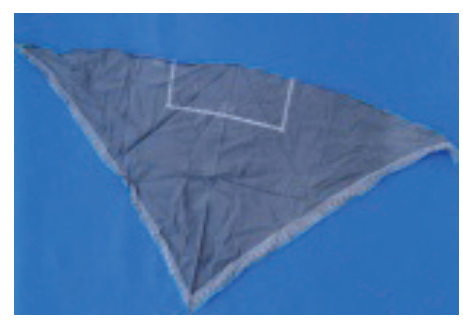

Keduabelas, Merak. Manik tasbih yang ada di paruh burung Merak merupakan ilustrasi dari sarana berzikir (mengingat Allah dengan menyebut nama Nya), yang selalu mengingatkan manusia agar senantiasa melakukannya di setiap saat. Diantara landasan Al Quran adalah QS Al-Ahzab: 41-42: "ya ayyuhalladzina amanu udzkuru Allaha dzikran katsiran wa sabbihuhu bukratan wa ashilan" ("Wahai orang-orang yang beriman berdzikirlah (dengan menyebut nama Allah), dzikir yang sebanyak-banyaknya. Dan bertasbihlah kepada-Nya di waktu pagi dan petang”). Ia juga mengandung makna bagaimana seharusnya menjaga lisan dengan menggunakannya untuk membiasakan perkataan yang baik. Hal ini dijelaskan di dalam QS al Baqarah: 263: "Perkataan yang baik dan pemberian maaf lebih baik daripada sedekah yang diiringi dengan caci maki."

Ketigabelas, Harimau. Kekuatan fisik dan psikis (lahir dan batin). Keberanian (syaja'ah) yang disimbolkan oleh perangkat Reyog ini. Di dunia hutan belantara, binatang ini dikenal dengan raja hutan yang memiliki kekuatan, kewibawaan, dan kekuasaan. Instrumen ini mengandung makna bagi kehidupan bahwa seseorang harus memiliki kekuatan lahir-batin agar mampu memberikan kemanfaatan bagi kehidupan ini. Kekuatan, kewibawaan, dan kekuasaan diperlukan bukan untuk melakukan kesombongan dan kerusakan, tetapi justru untuk melahirkan karya menuju kemanfaatan.

Keempatbelas, Pecut Samandhiman. Pecut Samandiman adalah sebagai simbol senjata pamungkas (senjati sakti terakhir) untuk melumpuhkan lawan/ musuh. Senjata ini dimiliki oleh seorang pemimpin untuk menyertai langkah kepemimpinannya berjalan dengan sempurna. Hal ini menggambarkan, bahwa seorang pemimpin haruslah memiliki integritas keilmuan dan kepribadian yang "mapan”, yang dilandaskan kepada al Quran dan as Sunnah, sehingga akan berjalan dan menjalankan roda kepemimpinannya berdasarkan kedua landasan tersebut. Pemimpin dengan karakter seperti inilah yang harus ditaati oleh rakyatnya, sebuah ketaatan untuk mendukung tugas khilafah di muka bumi dan bukan untuk mengkultuskannya. Di dalam Alqur'an masalah ini dinyatakan di dalam QS An Nisa:59: “...athi'u Allaha wa athi'u ar-rasula wa uli al-amri minkum fa in tanaza'tum fi syai'in farudduhu ila Allahi wa ar-Rasuli..." 
("Ta'atilah Allah dan ta'atilah Rasul-Nya dan ulil amri diantara kamu. Kemudian jika kamu berlainan pendapat tentang sesuatu, maka kembalikanlah ia kepada Allah (al Quran) dan RasulNya (as Sunnah)”.

\section{Ragam Tari Reyog Ponorogo}

Pertama, Tari Warok. Tokoh warok di dalam seni Reyog Ponorogo merupakan tokoh kharismatik yang menjadi rujukan bagi masyarakat Ponorogo dalam hal hidup dan kehidupan. Oleh karena itu, di dalam pentas Reyog, tari warok selalu dimunculkan di awal pentas. Lazimnya terdiri dari warok sepuh dan warok muda. Warok sepuh menggambarkan sifat "kesempurnaan" seorang tokoh. Pentas ini biasanya dominan bernuansa "pendadaran" (forum pewarisan ilmu dan kebijaksanaan) dari warok sepuh kepada warok muda. Substansi makna dari tari ini adalah amanat yang dipikulkan di pundak warok sepuh sesungguhnya merupakan teladan hidup sehingga wajib baginya untuk menghiasi diri dengan integritas keilmuan dan kepribadian yang sempurna. Petuahnya dalam berbagai bentuk yakni sikap, ucap, dan tindak menjadi jimat (menjadi sesuatu yang sangat berharga bagi kehidupan).

Kedua, Tari Jathil. Substansi nilai dari Tari Jathil adalah sebuah sikap patriot (perwira, pahlawan). Sikap patriotisme pada Tari Jathil ini dilandaskan pada firman Allah, misalnya QS Al-Anfal:60: 'wa a'iddu lahum ma istatha'tum min quwwatin wa min ribathi al-khairi turhibuna bihi 'aduww Allah wa 'aduwwakum wa akharina min dunihim la ta'lamunahum, Allahu ya'lamuhum, wa ma tunfiqu min syaiy' in fi sabilillahi yuwaffa ilaikum wa antum la tudhlamun." "Dan siapkanlah untuk menghadapi mereka kekuatan apa saja yang kamu sanggupi dan dari kuda-kuda yang ditambat untuk berperang (yang dengan persiapan itu) kamu menggetarkan musuh Allah, musuhmu, dan orang-orang selain mereka yang kamu tidak mengetahuinya sedang Allah mengetahuinya. Apa saja yang kamu nafkahkan pada jalan Allah niscaya akan dibalas dengan cukup kepadamu dan kamu tidak akan dianiaya").

Ketiga, Pujangganong. Nilai atau makna dari Tari Pujangganong (Pujangga Anom) yang terkesan lucu, banyak ulah, dan selalu membuat sensasi sebagai simbol bahwa hidup di dunia ini tidaklah selalu mulus dan lurus. Banyak hambatan dan cobaan dengan beragam jenis. Bahkan di dalam Islam telah menggariskan pemeluknya, bahwa semakin seseorang berkualitas kemusliman dan kemukminannya, maka semakin berat dan beraneka ragam cobaan atau ujian yang bakal diterimanya. Hamba yang memiliki keimanan tinggi, takkan larut oleh segala jenis ujian hidup, tetapi semuanya dihadapi 
dengan ketegaran hati yang terbalut optimisme tinggi. Hal ini dilandaskan pada firman Allah dalam QS Yusuf: 87: "wa la taiasu min rawh Allah innahu la yaiasu min rawh Allah illa al-qawm al-kafirun" "Dan janganlah kamu berputus asa dari rahmat Allah, sesungguhnya tiada berputus asa dari rahmat Allah, melainkan kaum kafir").

Keempat, Tari Klanasewandana. Substansi nilai/makna tari ini adalah tentang kepemimpinan yang adil dan bijaksana. Tari ini menggambarkan bagaimana seharusnya seorang pemimpin itu menjalankan kepemimpinan. Di samping harus memiliki integritas keilmuan, ia juga harus memiliki integritas kepribadian. Integritas keilmuan yang dipentaskan melalui tari ini mewujud pada figur Klanasewandana sebagai orang yang "sakti mandraguna" (telah mencapai puncak kesempurnaan), sehingga layak menjadi seorang pemimpin. Sementara integritas kepribadiannya tergambar di dalam sikap, ucap, dan tindaknya yang selalu berorientasi kepada kesejahteraan dan keadilan. Di dalam menjalankan roda kepemimpinan itu, sang Klana memiliki senjata pamungkas (senjata paripurna) yang bernama Pecut Samandiman.

Kelima, Tari Dhadhak Merak. Nilai/makna yang terkandung di dalam Tari Dhadhak Merak tersimpul di dalam keniscayaan sebuah ujian hidup. Bentuk dhadhak merak yang mirip dengan rumpun pohon bambu yang lebat, meliuk-liuk seolah hendak menerjang apapun yang berada di depannya, menggambarkan keniscayaan sebuah ujian hidup yang mesti diterima/dihadapi oleh semua orang. Makna simbol ini diharapkan memberikan kesadaran penuh pada masyarakat akan adanya ujian hidup tersebut, sehingga sejak awal mereka menyadarinya dan sekaligus telah mempersiapkan diri untuk menghadapinya dengan baik. Di dalamnya juga mengandung makna, bahwa dalam rangka menuju hidup yang baik, maka harus menghiasi diri menjadi orang yang kuat lahir dan batinnya sebagaimana simbol kepala harimau serta indah dan baik perilakunya seperti yang disimbolkan oleh burung merak.

Pilar-pilar pendidikan Islam yang terbabar di dalam seni Reyog Ponorogo sangat bermanfaat untuk mengembangkan model pembelajaran pendidikan Islam, terutama di sekolah. Secara garis besar tujuan pendidikan Islam, sebagaimana dipaparkan di dalam Alqur'an, diklasifikasikan menjadi tiga bagian, yakni: menjadikan hamba Allah yang beriman, mengantar anak didik menjadi khalifah, dan memperoleh kebahagiaan di dunia dan akhirat. Tujuan pendidikan karakter berbasis seni Reyog Ponorogo bukan merupakan tujuan pendidikan Islam, namun sangat relevan dengan tujuan pendidikan Islam. Tujuan pendidikan karakter sebagaimana terdapat di dalam nilai dan 
makna simbol seni Reyog sangat memberi peluang untuk terealisirnya nilainilai Alqur'an yang menjadi tujuan pendidikan Islam.

Metode pendidikan Islam yang diturunkan dari Alqur'an dan Hadis pada dasarnya sangat menyentuh perasaan, mendidik jiwa, dan membangkitkan semangat (an-Nahlawi: 1989). Metode tersebut adalah sebagai berikut: (1) metode hiwar (percakapan) Qur'ani dan nabawi; (2) metode kisah; (3) metode amtsal (perumpamaan); (4) metode keteladanan; (5) metode pembiasaan dan pengamalan; (6) metode ibrah dan mau'izah, metode targhib dan tarhib. Beberapa metode yang disarankan An-Nahlawi ini telah dipergunakan dalam pembelajaran karakter seni Reyog Ponorogo, terutama metode kisah, pembiasaan, dan keteladanan.

\section{Strategi Internalisasi Nilai-Nilai Pendidikan}

Penanaman karakter berbasis seni Reyog Ponorogo berupa nilai-nilai pendidikan dalam simbol dan ragam tari dilakukan melalui pembelajaran di kelas. Bentuk penanaman masing masing sekolah memang tidak sama, tergantung kepada fokus perhatian pihak sekolah. Di tingkat SLTA, yakni SMAN 1. SMAN 2, SMAN 3, dan SMA Muhammadiyah 1, upaya penanaman karakter melalui seni Reyog lebih intensif dibandingkan dengan yang dilakukan di tingkat SLTP/SMP. Pendidikan karakter di tingkat sekolah menengah atas (SMA) dilakukan dengan basis kurikulum yang sebenarnya jauh lebih "mapan", mengingat konsep kurikulum pendidikan karakter berbasis seni Reyog Ponorogo terlahir dari sekolah ini, sebagaimana dituturkan oleh Pembina Reyog SMAN 1 Ponorogo Bapak Hariyadi, bahwa kurikulum seni Reyog Ponorogo telah dilakukan pembahasan intens melalui workshop sejak tahun 2007. Fokus materi di dalam kurikulum Reyog SMAN 1 tidak hanya terarah pada seni tarinya, tetapi juga pada nilai dan makna seluruh instrumen Reyog Ponorogo. Penilaian atau evaluasi dilakukan dengan cara individual maupun kelompok dan dilakukan secara kolosal di kelas tiga, melalui pementasan akhir tahun. Di sini biasanya muncul kreasi yang sering "mengejutkan" dan menjadi tolok ukur keberhasilan pendidikan karakter yang telah dibina selama tiga tahun (mulai kelas satu).

Penanaman karakter melalui pembelajaran yang dilakukan di SMAN 2 Ponorogo jauh lebih sistematis dan terencana. Seni Reyog dimasukkan sebagai muatan lokal mulai tahun 2006/2007 sampai sekarang. Pembelajaran Reyog di sekolah ini dilakukan melalui intrakurikuler dan diwajibkan bagi kelas satu. Sedangkan di kelas dua dan tiga disampaikan melalui ekstrakurikuler. 
Karakter yang diturunkan, melalui pembelajaran seni Reyog meliputi: religius, jujur, toleransi, disiplin, kreatif, mandiri, demokratis, rasa ingin tahu, semangat kebangsaan, cinta tanah air, cinta damai, gemar membaca, peduli lingkungan, peduli sosial, tanggungjawab, menghargai prestasi, bersahabat, dan komunikatif (Marji, wawancara, 3 Agustus 2015). Penanaman karakter kepada Konco Reyog di sekolah (siswa), disamping melalui pembelajaran di kelas, juga dilakukan melalui kreasi pentas panggung (dilakukan di aula sekolah). Strategi internalisasi dikemas berdasarkan kurikulum 2013, meliputi program pekan, semester, dan tahunan. Materi pembelajaran meliputi: (1) Mengenal legenda asal usul Reyog Ponorogo (mengidentifikasi latar belakang dan versi yang ada dalam legenda Reyog Ponorogo; mengidentifikasi sejarah perkembangan Reyog Ponorogo di masyarakat; dan mengidentifikasi sebuah karya seni Reyog Ponorogo; (2) Mengapresiasi karya seni musik Reyog (mengidentifikasi fungsi dan latar belakang musik Reyog dalam konteks budaya masyarakat setempat; mengungkapkan pengalaman musikal dari hasil pengamatan terhadap pertunjukan Reyog); (3) Mengapresiasi dan mengekspresi diri melalui karya seni Tari Reyog (mengidentifikasi jenis, peran, karakter dan perkembangan Tari Reyog dalam konteks budaya masyarakat daerah setempat; mengidentifikasi gagasan untuk disusun kedalam kreasi Tari Reyog; menampilkan seni Tari Reyog dalam bentuk tari kelompok dan atau tunggal).

Sementara di sekolah menengah pertama, pendidikan karakter berasis seni Reyog Ponorogo, memang belum intens dan sistematis, seperti yang dilakukan di sekolah lanjutan atas. Di sekolah menengah ini, pendidikan karakter disampaikan secara integral melalui latihan dan pentas seni Reyog Ponorogo. Karakter warok, misalnya dijelaskan menjelang Tari Warok diajarkan/dipentaskan.

Penanaman karakter, sebagaimana dipaparkan di atas, memang belum secara sistematis mengikuti model pendidikan karakter seperti di anjurkan oleh para tokoh pendidikan karakter, misalnya, proses penanaman nilai budi pekerti/karakter berlangsung secara bertahap (Bukhari, 2002). Ada lima fase yang harus dilalui oleh peserta didik untuk memiliki moral atau karakter. "Pertama, knowing, yaitu mengetahui nilai-nilai. Kedua, comprehending yaitu memahami nilai-nilai. Ketiga, accepting yaitu menerima nilai-nilai. Keempat, internalizing yaitu menjadikan nilai sebagai sikap dan keyakinan. Kelima, implementing yaitu mengamalkan nilai-nilai” (Bukhori, 2002: 10). Sementara, tahapan atau fase transformasi karakter meliputi: receiving (menyimak), responding (menanggapi), valuing (memberi nilai), organization (mengorganisasikan nilai), 
dan characterization (karakterisasi nilai) (Bukhori, 2002: 10). Proses transformasi tersebut melibatkan empat unsur afektif, yaitu: minat (interest), sikap (attitude), nilai (value), dan apresiasi (appreciation) (Krathwohl, 1973: 36).

Proses pendidikan karakter melalui seni Reyog Ponorogo dilakukan dengan tahapan yang belum sistemik seperti pada teori di atas. Proses mengetahui dan memahami nilai dilakukan secara terpadu di dalam praktik tari. Oleh karena itu, dengan kondisi seperti ini detil-detil karakter tidak tersampaikan secara lengkap, terutama dari segi epistemologi di balik makna simbol Reyog tersebut. Proses transformasi karakter mulai dari menyimak, merespon, memberi nilai, mengorganisasi nilai, dan mengkarakterisasi nilai, dengan demikian, dilakukan dalam tahapan yang sangat umum, yakni melalui pembelajaran/praktik tari. Pengetahuan dan pemahaman lebih dominan pada aspek sejarah, legenda, dan varian seni Reyog Ponorogo. Proses transformasi, seperti di sarankan Krathwohl, di kalangan Konco Reyog bertitik temu pada minat tinggi mereka untuk melakukan seni Reyog Ponorogo. Kecintaan Konco Reyog Ponorogo terhadap seni Reyog ini melahirkan apresiasi yang sangat tinggi, sehingga sekalipun pendidikan karakter belum dilakukan secara maksimal, nilai-nilai karakter tertanam dengan kuat pada Konco Reyog Ponorogo.

\section{Relevansi Nilai Pendidikan dalam Seni Reyog Ponorogo dengan Pendidikan Karakter di Indonesia.}

Pilar pendidikan karakter yang dikembangkan di Indonesia terdiri dari 9 (Sembilan) pilar, yakni : (1) Cinta Tuhan dan segenap ciptaan-Nya; (2) Kemandirian dan tanggung jawab; (3) Kejujuran/amanah dan diplomatis; (4) Hormat dan santun; (5) Dermawan, suka tolong-menolong dan gotong-royong atau kerja sama; (6) Percaya diri dan kerja keras; (7) Kepemimpinan dan keadilan; (8) Baik dan rendah hati, dan (9) Toleransi, kedamaian, dan kesatuan (http:/ www.kemdiknas.go.id, diakses tanggal 4 April 2015). Aspek-aspek karakter ini, akan menjadi efektif kalau disampaikan melalui kurikulum, menggunakan pelajaran akademik sebagai kendaraan untuk membahas permasalahan etika (Licona, 2013: 107).

Dengan demikian, pendidikan karakter berbasis seni Reyog Ponorogo sangat relevan mendukung program pemerintah, terkait dengan pendidikan karakter. Karakter yang berhasil ditanamkan melalui seni Reyog Ponorogo ini meliputi: (1) cinta Tuhan dengan indikator ketaatan Konco Reyog untuk melakukan ibadah melalui berdoa dan menghentikan latihan untuk melakukan shalat sesuai waktu shalat yang hadir di saat latihan atau pentas; (2) kemandirian 
dan tanggungjawab nampak pada tugas yang diberikan kepada Konco Reyog, mereka secara individual maupun kelompok terbiasa untuk memikul tugas atau amanat yang diberikan oleh sekolah, baik yang terkait dengan seni Reyog Ponorogo maupun lainnya dari pihak sekolah ataupun guru dengan penuh tanggungjawab; (3) karakter gotong royong atau kerjasama terbentuk secara baik. Dalam latihan kerjasama ini terlihat di dalam budaya saling mengingatkan terhadap peran yang keliru. Sementara di dalam keseharian, karakter ini mewujud di dalam perilaku saling mengingatkan terhadap tugas-tugas studi maupun perilaku yang harus dilakukan atau tidak boleh dilakukan sesuai norma dan tata tertib sekolah.

\section{Simpulan}

Di dalam seni Reyog Ponorogo terkandung sejumlah nilai edukasi yang bisa dimanfaatkan untuk membentuk karakter luhur Konco Reyog Ponorogo, terutama bagi Konco reyog di sekolah melalui pembelajaran. Nilai-nilai pendidikan dalam seni Reyog Ponorogo, meliputi: pendidikan keimanan, pendidikan akhlak, pendidikan kepemimpinan, dan sebagainya. Nilai-nilai pendidikan tersebut ternyata sangat relevan dengan nilai-nilai pendidikan Islam, sehingga dalam perspektif ini, pendidikan karakter Konco Reyog bisa dititikmuarakan pada nilai-nilai ajaran Islam, mengingat basis keagamaan Konco Reyog sebagai umat Islam.

Nilai-nilai pendidikan yang terkandung di dalam seni Reyog Ponorogo telah diupayakan untuk ditransformasikan melalui pendidikan karakter di sekolah-sekolah di Ponorogo, baik melalui intrakurukuler maupun ekstra kurikuler. Dalam praktik, pendekatan pembelajaran yang digunakan meliputi praktis dan teoritis. Hanya saja sementara ini masih dominan menggunakan pendekatan praktis, sehingga hasilnya meskipun cukup baik, tetapi belum optimal. Sementara itu, penyajian secara teoritis belum dipergunakan secara maksimal, padahal model penyajian ini akan sangat mendukung penyajian praktis, karena penyajian teoritis dilakukan melalui proses yang terstruktur dengan menggunakan teori dan metode (Ratna, 2014: 196-197). Di samping itu juga dilakukan secara formal di dalam kelas, melalui diskusi, tanya jawab, dan seterusnya, serta melalui pembimbingan, yakni guru, dosen, dan para instruktur lainnya (Ratna, 2014: 196-197).

Pendidikan karakter melalui nilai-nilai karakter yang dikandung dalam seni Reyog Ponorogo bisa dipergunakan untuk menanamkan nilai-nilai karakter kepada Konco Reyog dengan sangat mudah, karena berbasis seni budaya (Reyog 
Ponorogo) yang secara implisit sudah mengandung kemenarikan. Sementara pada sisi yang lain, pendidikan karakter berbasis seni Reyog Ponorogo ini juga bisa dipergunakan untuk mendukung pelaksanaan pendidikan karakter di Indonesia, di samping juga dapat dipergunakan sebagai salah satu cara atau stategi untuk menguatkan upaya pelestarian dan pengembangan seni reyog Ponorogo mengingat seni budaya ini telah menjadi branding peradaban Ponorogo, khususnya dan Indonesia pada umumnya.

\section{Daftar Pustaka}

Alqur'an dan Terjemahnya. Madinah Munawwarah: Mujamma' al-Malik Fahd li Thiba'at al-Mushaf asy-Syarif.

Al Bukhari, Imam Abi 'Abdillah. tt. Sahih Bukhari. Semarang: Toha Putra.

Abdurrahman, An-Nahlawi. 1989. Prinsip-Prinsip Dasar Metode Pendidikan Islam dalam Keluarga, di Sekolah, dan di Masyarakat. Terjemahan oleh Herry Noer Ali . Bandung: Diponegoro.Frondizi, Risieri. 2011. Pengantar Filsafat Nilai. Terjemahan oleh Cuk Ananta Wijaya. Yogyakarta: Pustaka Pelajar.

Lickona, Thomas. 1992. Educating for Character: How Our School can Teach Respect and Responsibility. New York: Bantam Books.

Munawwir, AW. 1984. Kamus Arab-Indonesia. Yogyakarta: Pustaka Progressif.

Ranta, Nyoman Kutha. 2014. Karya Sastra, Seni, dan Budaya dalam Pendidikan Karakter. Yogyakarta: Pustaka Pelajar.

Roqib, Moh. 2007. Harmoni dalam Budaya Jawa (Dimensi Edukasi dan Keadilan Gender). Purwokerto: STAIN Purwokerto Press.

Sunan Ibnu Majah. tt. Semarang: Penerbit Toha Putra.

Zuchdi, Darmiyati. 2008. Humanisasi Pendidikan. Jakarta: PT Bumi Aksara. 